\title{
Analisis Plastik Biodegradable Berbahan Dasar
}

\section{Nasi Aking}

\author{
Sufiya Putri Martina ${ }^{1)}$, Masturi ${ }^{1)}$, Ian Yulianti ${ }^{1)}$ \\ 1) Prodi Pendidikan Fisika, Program PascaSarjana, Universitas Negeri Semarang \\ Gedung A Program PascaSarjana Unnes, Kampus Unnes Bendan Ngisor Semarang 50233 \\ E-mail: Sofiamartina.sm@gmail.com
}

\begin{abstract}
Abstrak. Lingkungan bagi manusia merupakan salah satu unsur yang sangat penting dalam kehidupannya, karena lingkungan tidak hanya sebagai tempat manusia beraktivitas, tetapi juga sangat berperan dalam mendukung berbagai aktivitas manusia. Lingkungan tidak jauh dengan adanya limbah. Tidak sedikit masyarakat yang menyisakan nasi dan membuangnya, sehingga nasi menjadi limbah. Limbah nasi sering dikenal sebagai nasi aking. Kandungan pati yang terdapat pada nasi aking dapat digunakan sebagai bahan baku pembuatan plastik biodegradable. Tujuan pada penelitian ini adalah untuk mengetahui laju penguraian atau biodegradasi plastik biodegradable terhadap lingkungan dengan variasi massa 5 gram, 8 gram, dan 11 gram. Untuk pencampuran kitosan dengan kadar 3 gr dan gliserol $2 \mathrm{~mL}$ diberikan dalam jumlah yang sama untuk masing-masing massa. Hasil dari penelitian ini didapatkan biodegradasi yang paling optimal dengan massa 8 gram selama 7 hari dan mempunyai kuat tarik $158.725 \mathrm{Kg} / \mathrm{cm} 2$.
\end{abstract}

\section{PENDAHULUAN}

Lingkungan bagi manusia merupakan salah satu unsur yang sangat penting dalam kehidupan, karena lingkungan tidak hanya sebagai tempat manusia beraktivitas, tetapi juga sangat berperan dalam mendukung berbagai aktivitas manusia. Lingkungan tidak jauh dengan adanya limbah. Banyak disekitar kita limbah bisa dimanfaatkan kembali ada juga limbah yang harus dibuang atau tidak dapat diolah menjadi bahan yang berdaya guna.

Dalam lingkungan sering kita menemui banyak jenis limbah, salah satunya adalah limbah nasi. Tidak sedikit masyarakat yang menyisakan nasi dan membuangnya, sehingga nasi menjadi limbah. Limbah nasi sering dikenal sebagai nasi aking. Nasi aking adalah nasi yang diperoleh dari sisa nasi yang telah dikonsumsi lalu dibuang dan diolah kembali. Pengolahan nasi aking menjadi nasi untuk dikonsumsi sama seperti mengolah beras menjadi nasi pada umumnya. Walaupun sudah diolah kembali menjadi nasi, nasi aking tidak memberi nilai gizi yang sama seperti nasi biasa karena sudah melalui proses yang panjang. Nasi aking merupakan nasi yang sudah tidak layak untuk dikonsumsi masyarakat, karena telah basi dan mengandung jamur dan mikroorganisme merugikan lainnya. Seiring dengan permasalahan ini, penelitian pembuatan plastik dari polimer alam yang mudah diuraikan berkembang dengan pesat. Kandungan pati yang cukup tinggi dari nasi aking dapat digunakan sebagai bahan baku pembuatan plastik biodegradable [1].

Berdasarkan bahan baku yang dipakai plastik biodegradable dibagi menjadi dua kelompok yaitu kelompok dengan bahan baku petrokimia seperti poli ( $\varepsilon$-kaprolakton), (PCL) dan kelompok dengan bahan baku produk tanaman seperti pati dan selulosa. Pati merupakan senyawa polisakarida yang terdiri dari monosakarida yang berikatan melalui ikatan oksigen. Monomer dari pati adalah glukosa yang berikatan dengan ikatan $\alpha(1,4)$ glikosidik, yaitu ikatan kimia yang menggabungkan 2 molekul monosakarida yang berikatan kovalen terhadap sesamanya. Pati merupakan zat tepung dari karbohidrat dengan suatu polimer senyawa glukosa yang terdiri dari dua komponen utama, yaitu amilosa dan amilopektin. Polimer linier dari D - glukosa [2].

Plastik biodegradable adalah polimer plastik yang tersusun atas monomer organik yang terdapat pada pati,selulosa,protein dan mikroorganisme. Plastik biodegradable dapat digunakan layaknya 


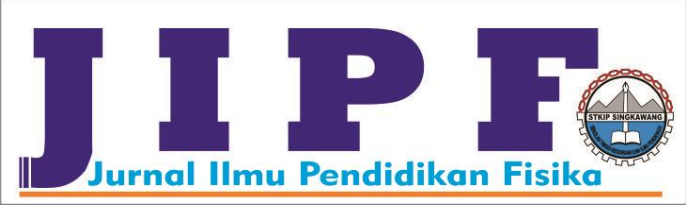

plastik konvensional biasa namun akan hancur oleh aktivitas mikroorganisme dan menghasilkan air dan senyawa yang tidak berbahaya bagi lingkungan dan kesehatan ketika dibuang kelingkungan [3].

\section{METODOLOGI PENELITIAN}

A. Alat yang digunakan:

1. Oven

2. Gelas ukur

3. Pengaduk kaca

4. Termometer

5. Magnetic stirrer

6. Glas beker

7. Spatula besi

8. Neraca analiti

B. Bahan yang dibutuhkan :

1. Nasi aking

2. Gliserol

3. Kitosan

4. Aquades

5. $\mathrm{CH}_{3} \mathrm{COOH}$

C. Prosedur Penelitian

1. Pretreatment Tepung Nasi Aking

a. Pengambilan limbah nasi dari tetangga dan sebagian sudah kering

b. Nasi aking dikeringkan dengan dijemur pada sinar matahari. Untuk benar-benar memastikan kadar air hilang, dioven selama 3 jam dengan suhu 750 .

c. Setelah kering dan menjadi nasi aking selanjutnya dihaluskan dengan penggilingan tepung agar bisa larut dalam air

2. Proses Pembuatan Plastik biodegradable

a. 3 gram, 5 gram, dan 7 gram tepung nasi aking masing-masing dilarutkan dengan $50 \mathrm{ml}$ asam asetat $2 \%$ dengan pengadukan pada temperature $80^{\circ} \mathrm{C}$ selama 10 menit

b. 3 gram kitosan dilarutkan dengan $100 \mathrm{ml}$ asam asetat $2 \%$ dengan pengadukan selama 30 menit pada temperatur $80^{\circ} \mathrm{C}$

c. Setelah semua larutan larut, larutan nasi aking dicampurkan ke larutan
Jurnal Ilmu Pendidikan Fisika

Volum 1 Nomor 1 Maret 2016. Halaman 9-12 p-ISSN: 2477-5959 e-ISSN: 2477-8451

kitosan dengan pengadukan selama 15 menit

d. Ditambahkan dengan gliserol $4 \mathrm{ml}$ dan melakukan pengadukan dan pemanasan selama 10 menit dan temperatur mencapai $80^{\circ} \mathrm{C}$

e. Cetakan dibersihkan dengan alkohol $96 \%$ dan selanjutnya menuangkan larutan plastik biodegradable ke cetakan

f. Dimasukkan kedalam oven dengan temperatur $75^{\circ} \mathrm{C}$ selama 20 jam

g. Mengeluarkan cetakan dari oven dan didinginkan pada temperatur kamar

Plastik biodegradable siap dianalisis

Pada proses pembuatan plastik biodegradable dilakukan variasi komposisi bahan pembuatan plastik biodegradable dengan variasi massa tepung nasi aking 3 gr, 5 gr, dan 7 gr.

\section{Pengujian Hasil Plastik biodegradable}

1. Kuat Tarik

Sampel yang akan diuji terlebih dahulu dikondisikan dalam ruang dengan temperature dan kelembaban standar $(23 \pm 20 \mathrm{C}, 52 \%)$ selama 24 jam. Sampel yang akan diuji dipotong sesuai standar yaitu $2 \mathrm{x}$ $8 \mathrm{~cm}$. Pengujian dilakukan dengan cara kedua ujung sampel dijepit. Selanjutnya dicatat panjang awal sebelum penambahan beban. Setelah dicatat film yang telah dijepit ditambahkan beban Selanjutnya dilakukan pengujian lembar berikutnya. Perhitungan :

Kekuatan Tarik $(\mathrm{kg} / \mathrm{cm} 2)=\frac{\text { gaya kuat tarik }(\mathrm{F})}{\text { luas permukaan }(A)}$

2. Uji Biodegradasi

Kemudian setelah diuji sifat mekaniknya maka tahap uji berikutnya adalah uji biodegradable dengan cara sampel ditanam didalam tanah dengan kedalaman $30 \mathrm{~cm}$ dan dibiarkan selam 60 hari dengan pengamatan setiap 15 hari. Sebelum penanaman ditimbang dan diukur terlebih dahulu sampel yang akanditanam tersebut. Sampel uji diambil dan dibersihkan, dicuci dengan aquades kemudian direndam dengan alkohol $70 \%$ selama 5 menit. Selanjutnya dikeringkan dalam oven pada temperatur 


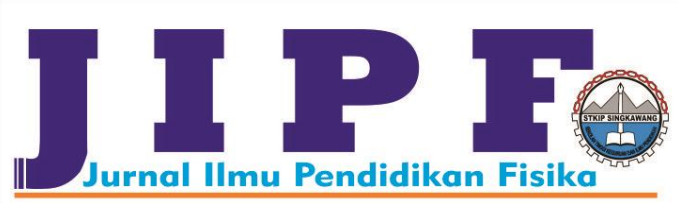

$60^{\circ} \mathrm{C}$ selama 1 hari. Sampel ditimbang kembali menggunakan neraca analitis. Perlakuan ini dilakukan untuk semua sampel yang diteliti. Persen kehilangan berat dapat dihitung dengan menggunakan rumus:

$$
\% \text { kehilangan berat }=\frac{W_{1}-W_{2}}{W_{1}} \times 100 \%
$$

Dimana :

$\mathrm{W}_{1}=$ Berat plastik sebelum di uji biodegredasi

$\mathrm{W}_{2}=$ Berat plastik setelah di uji biodegredasi

\section{HASIL DAN PEMBAHASAN}

An Penelitian yang dilakukan tentang plastik biodegradable berbahan dasar tepung nasi aking dengan variasi massanya. Hasil dari penelitian ini dapat dilihat pada Gambar.

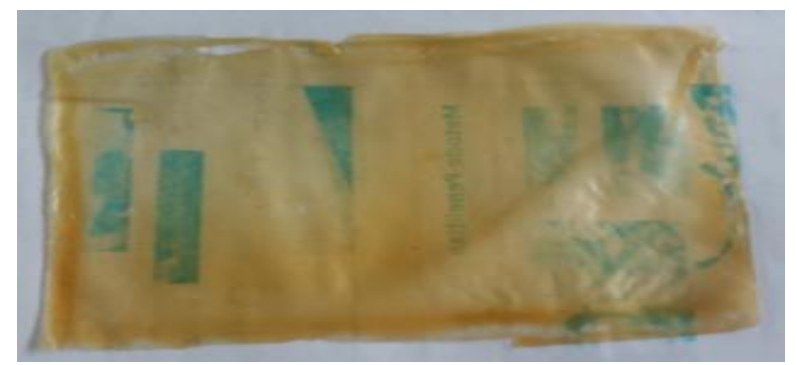

Gambar 1 Plastik biodegradable dengan massa tepung 7 gram
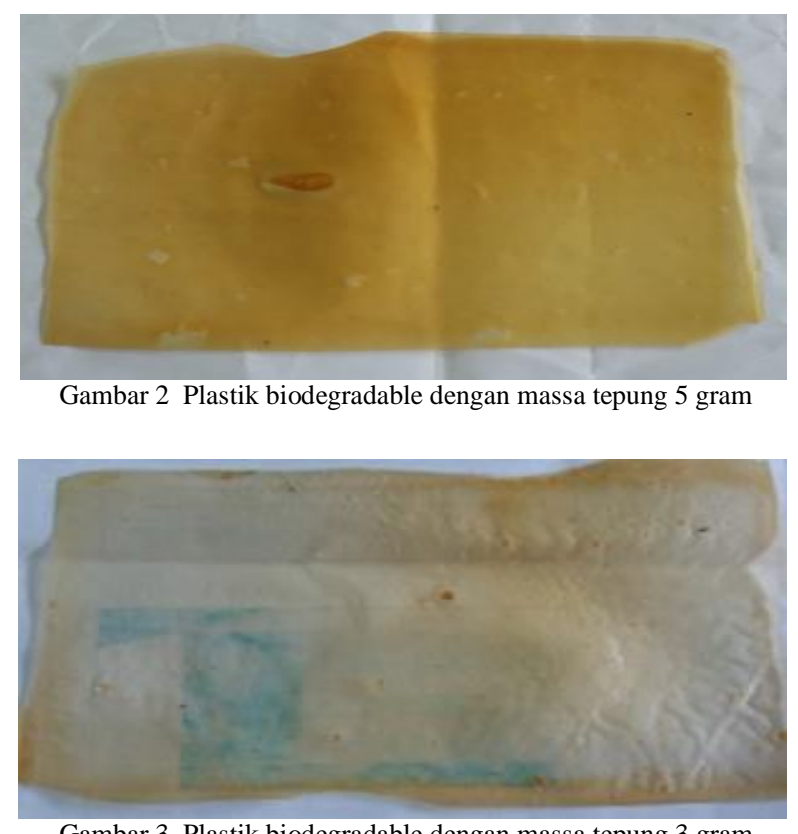

Gambar 3 Plastik biodegradable dengan massa tepung 3 gram
Jurnal Ilmu Pendidikan Fisika

Volum 1 Nomor 1 Maret 2016. Halaman 9-12 p-ISSN: 2477-5959 e-ISSN: 2477-8451

Gambar 1, 2 dan 3 merupakan plastik biodegradable dengan massa yang berbeda dan dapat dilihat hasilnya juga berbeda. Untuk 7 gram terlihat tebal dan kuning memiliki ketebalan 0,67 mm. Sedangnkan untuk massa 5 gram dan 3 gram warnanya semakin pudar dan kelihatan tipis memiliki ketebalan 0,48 $\mathrm{mm}$ dan 0,29 mm. Plastik biodegradable dibuat dengan tambahan kitosan dan gliserol dalam jumlah yang sama yaitu masing-masing 3 gram dan $2 \mathrm{ml}$. Bau yang ditimbulkan asam karena adanya campuran asam asetat sebagai pelarut tepung dan kitosan.

Cjxrkxhgchjfuk,cj

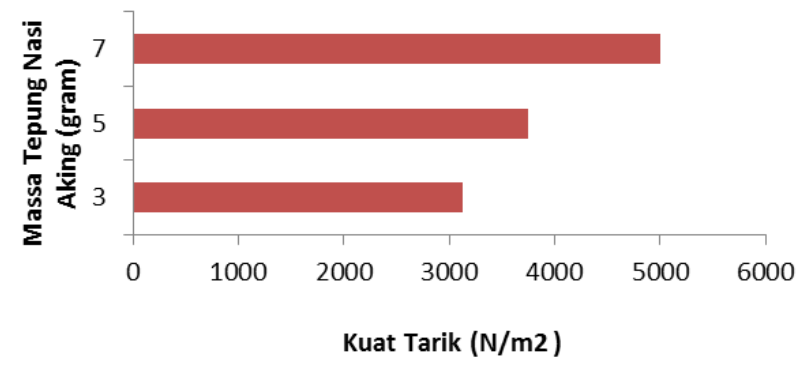

Gambar 4 Grafik pengaruh massa nasi aking terhadap kuat tarik

Dari Gambar 4 dapat dilihat bahwa semakin banyak massa yang digunakan, kuat tariknya semakin besar dan pada grafik semakin naik. Naiknya nilai kuat tarik disebabkan oleh partikel bioplastik banyak mengalami perubahan fisika, sehingga plastik semakin homogen dan strukturnya semakin rapat. Selain itu, banyak atau sedikitnya massa juga mempengaruhi tebal dan tipisnya plastik. Semakin tebal plastik maka kuat tariknya akan semakin besar dan semakin tipis plastik kuat tariknya semakin kecil.

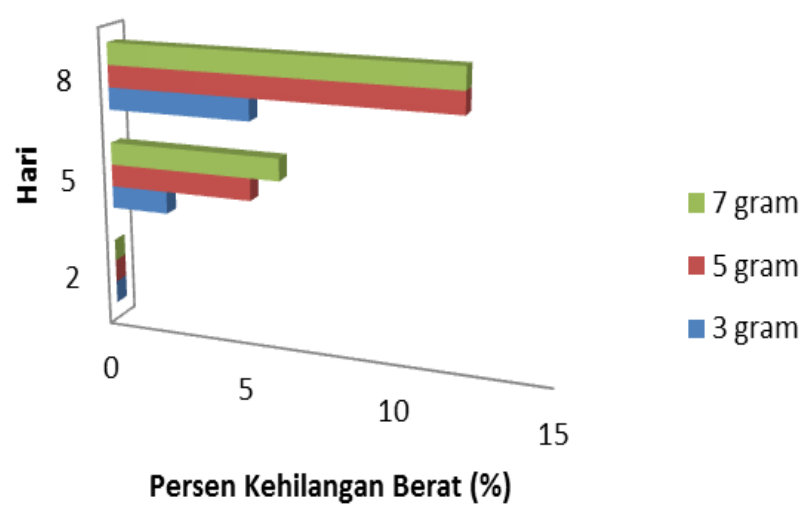

Gambar 5 Grafik Biodegradasi Plastik Biodegradable 
Gambar 5 menjelaskan mengenai biodegradasi plastik biodegradable. Pada grafik dapat dilihat bahwa plastik biodegradable yang mempunyai komposisi massa lebih banyak terjadi biodegradasi tinggi. Sedangkan plastik biodegradable yang mempunyai komposisi massa semakin sedikit terjadi biodegradasi rendah. Hal tersebut dapat dibuktikan dengan persen kehilanagan berat masing-masing plastik. Untuk hari kedua, plastik belum mengalami biodegradasi dengan pembuktian tidak terjadi kehilangan berat atau berat masih sama seperti keadaan awal.

\section{IV.SIMPULAN DAN SARAN}

\section{A. Simpulan}

Dari hasil penelitian dapat diambil kesimpulan bahwa semakin banyak komposisi massa ditambahakan dengan konsentrasi yang sama, maka untuk kuat tarik dan biodegradasi mempunya perubahan yang tinggi. Hal tersebut dikarenakan adanya konsetrasi yang sama dicampurkan dengan massa yang berbeda yaitu 3 gram, 5 gram dan 7 gram. Sehingga untuk massa yang kecil konsentrasinya tinggi sehingga tidak mudah sobek dan mempunyai kuat tarik yang lebih kecil yaitu 3x103. Sedangkan massa yang lebih banyak akan mempunyai konsetrasi lebih sedikit sehingga akan mudah sobek.

\section{B. Saran}

Para peneliti dapat membuat plastik biodegradable yang lebih bagus lagi. Karena penelitian ini masih banyak kekurangan dari konsetrasi pembuatan hingga waktu biodegradasinya. Sehingga disarankan untuk penelitian selanjutnya dapat membuat plastik dengan bahan lain atau dengan konsentrasi yang lebih sempurna dan juga menambah waktu biodegradasi plastik.

\section{DAFTAR PUSTAKA}

[1] Selfiana, Jeo F. R. , dan Kevin Yordan. 2014. Pembuatan Plastik Biodegradable Dari Tepung Nasi Aking. Jurusan Teknik Kimia

[2] Anita, Zulisma, Akbar F. dan Harahap H. 2013. Pengaruh Penamabahan Gliserol Terhadap Sifat Mekanik Film Plastik Biodegradasi Dari Pati Kulit Singkong. Jurnal Teknik Kimia USU Vol. 2, No.2

[3] Sinaga,R.F. 2014. Pengaruh Penambahan Gliserol Terhadap Siha Kekuatan Tarik Dan Pemanjangan Saat Putus Bioplastik Dari Pati Umbi Talas. Jurnal Teknik Kimia USU, Vol. 3, No 2.Metev and V. P. Veiko, Laser Assisted Microtechnology, 2nd ed., R. M. Osgood, Jr., Ed. Berlin, Germany: Springer-Verlag, 1998. 